\title{
Does undetectable basal Tg measured with a highly sensitive assay in the absence of antibodies and combined with normal ultrasonography ensure the absence of disease in patients treated for thyroid carcinoma?
}

\author{
Tireoglobulina basal indetectável medida com ensaio \\ ultrassensível na ausência de anticorpos e combinada \\ com ultrassonografia normal assegura ausência de \\ doença em pacientes tratados de câncer de tireoide?
}

Pedro Weslley Rosário', Augusto Flávio Campos Mineiro Filho'

1 Núcleo de Pós-Graduação da Santa Casa de Belo Horizonte, Belo Horizonte, MG, Brazil
Correspondence to: Pedro Weslley Rosário

Núcleo de Pós-Graduação da Santa Casa de Belo Horizonte

Av. Francisco Sales, $1111,8^{\circ} \mathrm{C}$ 30150-221 - Belo Horizonte, MG, Brazil

pedrorosario@globo.com

Received on Jul/18/2011 Accepted on Feb/24/2012

\section{SUMMARY}

It has been proposed that, in patients treated for well-differentiated thyroid carcinoma, undetectable basal thyroglobulin $(\mathrm{Tg})$ levels measured with a highly sensitive assay in the absence of anti-thyroglobulin antibodies ( $\mathrm{TgAb}$ ) and combined with negative neck ultrasonography (US) ensured the absence of disease. We report a series of five patients with well-differentiated (papillary) carcinoma submitted to total thyroidectomy with apparently complete tumor resection, followed by remnant ablation with ${ }^{131}(100-150 \mathrm{mCi})$, who had no distant metastases upon initial post-therapy whole-body scanning. When tumor recurrence or persistence was detected, these patients presented undetectable basalTg $(0.1 \mathrm{ng} / \mathrm{mL})$ in the absence of TgAb, and US showed no anomalies. Two patients had lymph node metastases, one had mediastinal metastases, bone involvement was observed in one patient, and local recurrence in one. We conclude that further studies are needed to define in which patients undetectable basal Tg (negative TgAb) combined with negative US is sufficient, and no additional tests are required. Arq Bras Endocrinol Metab. 2012;56(2):149-51

\section{SUMÁRIO}

Tem sido proposto que em pacientes tratados de carcinoma bem diferenciado da tireoide o encontro de valores basais indetectáveis de tireoglobulina $(\mathrm{Tg})$, dosada por ensaios ultrassensíveis, na ausência de anticorpos antitireoglobulina ( $\mathrm{TgAc}$ ), e combinado à ultrassonografia (US) cervical negativa, asseguraria ausência de doença. Reportamos aqui uma série de cinco pacientes com carcinoma bem diferenciado (papilífero), submetidos à tireoidectomia total, com ressecção tumoral aparentemente completa, seguida da ablação de remanescentes com ${ }^{131}$ I (100-150 mCi), sem metástases distantes na pesquisa de corpo inteiro pós-dose inicial, que, na ocasião em que a recorrência ou persistência tumoral foi detectada, apresentavam $\mathrm{Tg}$ basal indetectável $(0.1 \mathrm{ng} / \mathrm{ml}), \mathrm{TgAc}$ negativos e US sem anormalidades. Dois pacientes tinham metástases linfonodais, um tinha mediastinal, outro acometimento ósseo e um recorrência local. Concluímos que mais estudos são necessários para a definição de que pacientes com Tg basal indetectável (sem TgAc) combinada à US sem anormalidades seria suficiente, dispensando testes adicionais. Arq Bras Endocrinol Metab. 2012;56(2):149-51 


\section{INTRODUCTION}

$\mathrm{M}$ easurement of serum thyroglobulin $(\mathrm{Tg})$ is considered to be the most sensitive method for the detection of persistent or recurrent disease in patients with differentiated thyroid carcinoma after initial therapy. Obviously, the sensitivity of this marker is limited in patients with poorly differentiated tumors that do not secrete $\mathrm{Tg}$, or in patients with circulating anti-thyroglobulin antibodies ( $\mathrm{TgAb})$ that interfere with serum $\mathrm{Tg}$ measurement (false reduction). In addition, positive serum $\mathrm{Tg}$ result depends on the secretion of sufficient amounts, which can be detected by the assay. The use of highly sensitive assays enables the detection of even minimal amounts of $\mathrm{Tg}$ in the circulation, which would not be identified by traditional assays. The exceptional cases of persistent/recurrent disease, in which basal (no TSH stimulation) Tg levels may be undetectable with these assays, would be due to small cervical lymph node metastases or local recurrence (1-7), which could be identified by ultrasonography (US). Therefore, the observation of undetectable basal Tg levels measured by highly sensitive assays in patients with well-differentiated tumors, in the absence of circulating $\mathrm{TgAb}$ and combined with negative US, ensures the absence of disease at that time, and as along as the results continue the same $(1,2,4-6,8)$. We report here a series of five patients who exhibited tumor persistence or recurrence despite the presence of this combination of findings.

\section{CASE REPORT}

All patients had well-differentiated thyroid carcinoma (papillary type) and had undergone total thyroidec- tomy with apparently complete tumor resection, followed by remnant ablation with 131I (3.7-5.5 GBq). Initial post-therapy whole-body scanning (RxWBS) revealed no distant metastases. When tumor persistence or recurrence was detected, all patients presented undetectable basal $\mathrm{Tg}(0.1 \mathrm{ng} / \mathrm{ml})$ in the absence of $\mathrm{TgAb}$, and US showed no anomalies. The characteristics of each patient are shown in Table 1.

Tg was measured with a highly sensitive chemiluminescent assay (Tg Access, Beckman Coulter, Fullerton, $\mathrm{CA}$ ), with functional sensitivity of $0.1 \mathrm{ng} / \mathrm{mL}$. This assay had been used in recent series $(1,2,4,5,7)$. TgAb were determined by a chemiluminescent assay (Immulite 2000), with a detection limit of $20 \mathrm{IU} / \mathrm{mL}$, and reference value of up to $40 \mathrm{IU} / \mathrm{mL}$.

Ultrasonography was performed with a linear multifrequency $10-\mathrm{MHz}$ transducer. RxWBS was performed with a therapeutic dose of 131I (3.7-5.5 GBq), after stimulation with recombinant human TSH (rhTSH) and administration of a low-iodine diet for the 10 days before the examination. Anterior and posterior whole-body images were obtained 7 days after iodine administration. FDG-PET was also carried out after stimulation with rhTSH. Computed tomography (CT) was performed on 5-10 mm sequential sections.

\section{DISCUSSION}

Several studies have evaluated the performance of highly sensitive $\mathrm{Tg}$ assays in patients treated for differentiated thyroid carcinoma without circulating TgAb. All of these series included patients with persistent/recurrent disease in the presence of undetectable basal $\mathrm{Tg}$ (1-7). Therefore, the observation of undetectable basal

Table 1. Characteristics and test results of the patients

\begin{tabular}{|c|c|c|c|c|c|c|c|c|c|}
\hline Gender & $\begin{array}{c}\text { Age } \\
\text { (years) }\end{array}$ & Histology & $\begin{array}{l}\text { Tg immuno- } \\
\text { histochemistry }\end{array}$ & TNM* $^{*}$ & $\begin{array}{l}\text { Initial } \\
\text { RxWBS }\end{array}$ & $\begin{array}{l}\text { Time since } \\
\text { diagnosis } \\
\text { (months after } \\
\text { ablation) }\end{array}$ & $\begin{array}{l}\text { Stimulated Tg } \\
(\mathrm{ng} / \mathrm{ml})\end{array}$ & $\begin{array}{l}\text { Site of } \\
\text { recurrence }\end{array}$ & $\begin{array}{l}\text { Positive } \\
\text { diagnostic } \\
\text { methods }\end{array}$ \\
\hline $\mathrm{F}$ & 74 & $\begin{array}{c}\text { PTC (tall cell), } \\
\text { vascular invasion }\end{array}$ & Positive & T4N1 & $\mathrm{TB}$ & 18 & 0.9 & Bone & $\begin{array}{c}\text { CT, scintigraphy, } \\
\text { RxWBS }\end{array}$ \\
\hline $\mathrm{F}$ & 49 & Classical PTC & Positive & T3N1 & Cervical LN & 8 & 0.26 & $\mathrm{LN}$ & RxWBS \\
\hline $\mathrm{F}$ & 34 & Classical PTC & Positive & T3N1 & Cervical LN & 8 & 0.31 & $\mathrm{LN}$ & RxWBS \\
\hline $\mathrm{F}$ & 72 & $\begin{array}{c}\text { Classical PTC, } \\
\text { vascular invasion }\end{array}$ & Positive & T4NO & $\mathrm{TB}$ & 12 & 0.18 & $\mathrm{~TB}$ & $\begin{array}{l}\text { FDG-PET, } \\
\text { histology }\end{array}$ \\
\hline M & 32 & Classical PTC & Positive & T2NO & $\mathrm{TB}$ & 24 & 0.2 & Mediastinum & $\begin{array}{l}\text { FDG-PET, } \\
\text { histology }\end{array}$ \\
\hline
\end{tabular}


$\mathrm{Tg}$ even in the absence of $\operatorname{TgAb}$, and measured with a highly sensitive assay does not rule out the need for imaging methods. Considering that these false-negative cases are cervical lymph node metastases or local recurrence (1-7), ultrasonography is the complementary method of choice. Even this combination (undetectable basal $\mathrm{Tg}$ measured with a highly sensitive assay, negative $\mathrm{TgAb}$, and normal ultrasonography) does not ensure the absence of long-term recurrence $(6,7)$. Moreover, these cases of recurrence have been described even when $\mathrm{Tg}$ continued to be undetectable $(6,7)$, suggesting that follow-up using exclusively basal $\mathrm{Tg}$ and $\mathrm{TgAb}$ is not sufficient, even when the measurements are performed with new assays. Periodic ultrasonography is a valuable tool for the identification of these cases $(6,7)$.

More interestingly, Giovanella and cols. (3) reported the case of a patient with undetectable basal $\mathrm{Tg}$, negative $\mathrm{TgAb}$ and normal ultrasonography who had local recurrence detected by FDG-PET. Similarly, Brassard and cols. (7) reported the case of a patient who was diagnosed with distant (bone) metastases (not identifiable by ultrasonography), although $\mathrm{Tg}$ continued to be undetectable and $\operatorname{TgAb}$ continued to be negative. These cases may be added to those reported here, in which the disease was detected even in patients with undetectable basal $\mathrm{Tg}$ measured with a highly sensitive assay and had negative $\operatorname{TgAb}$, with ultrasonography showing no disease. It should be noted that the patients described by those authors $(3,7)$, and the patients reported here had well-differentiated thyroid carcinoma, and immunohistochemistry for $\mathrm{Tg}$ was positive in the present series, a finding demonstrating the initial ability of the tumor to produce this protein.

It is recognized that these cases (metastases in patients with undetectable basal $\mathrm{Tg}$ measured with a highly sensitive assay - without $\mathrm{TgAb}$ - combined with negative ultrasonography) are not common, and that the best approach to identify them ( $\mathrm{Tg}$ stimulation, FDG-PET or others) is a challenge. Diagnostic wholebody scanning is clearly not an interesting option for these patients with negative basal $\operatorname{Tg}(9)$. These cases show that, in addition to the major concern related to their lower specificity (10), the use of highly sensitive $\mathrm{Tg}$ assays also requires further studies investigating their sensitivity and the necessary complementary investigation in cases of undetectable basal $\mathrm{Tg}$. In fact, the Latin American Thyroid Society (LATS) does not recommend the routine use of low functional sensitivity $\mathrm{Tg}$ assays until more evidence is published regarding their efficacy (10).

We conclude that further studies are needed to define for which patients undetectable basal $\mathrm{Tg}$ (negative $\mathrm{TgAb}$ ) combined with negative neck ultrasonography is sufficient, and no additional tests are required.

Disclosure: no potential conflict of interest relevant to this article was reported.

\section{REFERENCES}

1. Rosario PW, Purisch S. Does a highly sensitive thyroglobulin ( $\mathrm{Tg}$ ) assay change the clinical management of low-risk patients with thyroid cancer with $\mathrm{Tg}$ on $\mathrm{T} 4<1 \mathrm{ng} / \mathrm{ml}$ determined by traditional assays? Clin Endocrinol. 2008;68:338-42.

2. lervasi A, lervasi G, Ferdeghini M, Solimeo C, Bottoni A, Rossi L, et al. Clinical relevance of highly sensitive Tg assay in monitoring patients treated for differentiated thyroid cancer. Clin Endocrinol. 2007;67:434-41.

3. Giovanella L, Ceriani L, Ghelfo A, Maffioli M, Keller F, Spriano G. Thyroglobulin assay during thyroxine treatment in low-risk differentiated thyroid cancer management: comparison with recombinant thyrotropin stimulated assay and inaging procedures. Clin Chem Lab Med. 2006;44:648-52.

4. Castagna MG, Tala Jury HP, Cipri C, Belardini V, Fioravanti C, Pasqui $L$, et al. The use of ultrasensitive thyroglobulin assays reduces but not abolishes the need for TSH stimulation in patients with differentiated thyroid carcinoma. J Endocrinol Invest. 2011;34(8):e219-23. Epub 2011 Mar 7.

5. Smallridge RC, Meek S, Morgan MA, Gates GS, FoxTP, Grebe S, et al. Monitoring thyroglobulin in a sensitive immunoassay has comparable sensitivity to recombinant human $\mathrm{TSH}$-stimulated thyroglobulin in follow-up of thyroid cancer patients. J Clin Endocrinol Metab. 2007;92:82-7.

6. Giovanella L, Maffioli M, Ceriani L, De Palma D, Spriano G. Unstimulated high sensitive thyroglobulin measurement predicts outcome of differentiated thyroid carcinoma. Clin Chem Lab Med. 2009;47:1001-4.

7. Brassard $M$, Borget I, Edet-Sanson A, Giraudet AL, Mundler O, Toubeau $M$, et al. Long-term follow-up of patients with papillary and follicular thyroid cancer: a prospective study on 715 patients. J Clin Endocrinol Metab. 2011;96:1352-9.

8. Zöphel K, Wunderlich G, Smith BR. Serum thyroglobulin measurements with a high sensitivity enzyme-linked immunosorbent assay: is there a clinical benefit in patients with differentiated thyroid carcinoma? Thyroid. 2003;13:861-5.

9. Rosario PW. Câncer de tireóide: seguimento com radioiodo. In: Volpi E, Friguglietti C, Kulcsar MA. Câncer da tireóide. Abordagem multidisciplinar. $1^{\text {th }}$ ed. São Paulo: AC Farmacêutica; 2010. p. 280-3.

10. Pitoia F, Ward L, Wohllk N, Friguglietti C, Tomimori E, Gauna A, et al. Recommendations of the Latin American Thyroid Society on diagnosis and management of differentiated thyroid cancer. Arq Bras Endocrinol Metabol. 2009;53:884-7. 